\title{
CAMPING TOURISM EXPERIENCE, SATISFACTION AND LOYALTY: AN EMPIRICAL STUDY FROM CROATIA
}

\author{
Tihana Cegur Radović \\ Dina Lončarić \\ Josipa Cvelić Bonifačić
}

https://doi.org//10.20867/tosee.06.54

\begin{abstract}
Purpose - The purpose of this paper is to determine the impact of different dimensions of the camping tourism experience on satisfaction and loyalty. To achieve the purpose of this research, it was necessary to adjust and validate the measurement scale of the tourism experience in campsites. Furthermore, the goal was to investigate the relationship between camping tourists' satisfaction and their loyalty to the camp.

Methodology - An analysis of the recent literature on the topic of tourism experience and camping tourism was performed. Empirical research was conducted on a convenience sample of 143 visitors to campsites. Descriptive and multivariate statistics were used in the data analysis. Reliability analysis and exploratory factor analysis were applied. Hypotheses were tested using multiple regression analysis. Data analysis was performed using the software package IBM SPSS Statistic Version 26.

Findings - The results of empirical research show that of the four extracted dimensions of the camping tourism experience, three have a positive and significant impact on tourist satisfaction and loyalty. These are education, escapism and aesthetics, while entertainment has no significant impact.

Contribution - This research represents a starting point for further research about the camping tourism experience. The scale for measuring the camping tourism experience was validated and can be used in further research. Also, the results can help managers to develop marketing strategies and tactics, as the determinants of the tourism experience of camping tourists have been established.
\end{abstract}

Keywords: camping tourism, tourism experience, satisfaction, loyalty, Croatia

\section{INTRODUCTION}

Camping tourism has been recognised as a developing segment of the tourism industry (O`Neill et al. 2010; Mikulić et al. 2017). It has been defined as a form of special interest nature-based tourism (Mikulić et al. 2017). Camping was a major research subject in leisure studies in the 1960s and 1970s (Garst et al. 2010). With new trends emerging, camping demand has since changed considerably, from conventional campsites with only a tent and a campfire to modern campsites providing a variety of sophisticated amenities for the convenience of campers. Today, campers want a unique experience which exceeds the experience of nature and social interaction (Garst et al. 2010; Mikulić et al. 2017). The question arises of how to improve the tourism experience and make camping tourists satisfied and loyal visitors. 
ToSEE - Tourism in Southern and Eastern Europe, Vol. 6, pp. 817-834, 2021.

T. Cegur Radović, D. Lončarić, J. Cvelić Bonifačić: CAMPING TOURISM EXPERIENCE ...

In Europe, camping tourism began gaining popularity in the second half of the $20^{\text {th }}$ century. Given the mass nature of camping tourism, it became crucial for the development of tourism in Europe (Cvelić Bonifačić and Milohnić 2014). At the beginning of the $21^{\text {st }}$ century, the Mediterranean, as a camping destination for Europeans, is in its maturity phase and is gradually entering the saturation and decline phase of its life cycle (Cegur Radović 2021). "Silver tourism" has become a recent trend in camping, with a growing number of senior tourists over the age of 65 staying in campsites (Cegur Radović 2021). The differentiation strategy was a way out of the maturity phase of camping tourism, through various forms of innovations from mobile homes, bungalows, glamping tents to the modern caravans.

As in many other countries, camping tourism in Croatia is in its mature phase and a new experience has to be created to attract tourists to a given tourist destination. Croatia's camping potential lies in satisfied and loyal tourists, natural attractions, and quality accommodation. The social and sociological significance of camping tourism, together with the beauty of the environment, is especially highlighted. A number of studies have been conducted, regarding, for example, booking in Croatian campsites, duration of stay, average number of tourists per plot, and the habits and attitudes of camping tourists during pre-season and post-season (Cvelić Bonifačić et al. 2017; Mikulić et al. 2017; Rantala and Varley 2019; Van Heerden 2020). Nevertheless, this still remains a fairly under-researched area. There is also growing interest in the development of camping tourism in continental Croatia and in the development of glamping. No research has been conducted in Croatia dealing with the tourism experience in campsites, however.

The tourism experience is a complex and very personal construct (Urry 1990, Neuhofer et al. 2013). It is regarded a personal phenomenon with an extremely emotional meaning gained through product and services use (Cohen, 1979; Holbrook and Hirshman 1982; Neuhofer et al. 2013). Larsen (2007) points to the tourism experience as kind of an accumulated psychological phenomenon which includes pre-travel expectations, perceptions during the travel and post-travel memories (Sheng and Chen 2013). A number of studies have been conducted on the tourism experience in various areas. To the best of the authors knowledge, however, there is still insufficient research on the tourism experience in campsites. In fact, despite its popularity, camping, as a specific type of tourism, has been overlooked in scientific research in tourism and hospitality (Brooker and Joppe 2013; Gračan and Birin 2013; Andrey et al. 2014; Milohnić and Cvelić Bonifačić 2015; Criddle 2016; Brochado et al. 2016; Cvelić Bonifčić et al. 2017; Mikulić et al. 2017; Lopes and Brandâo 2018; Rantala and Varley 2019; Van Heerden 2020). In recent years, however, more attention is being paid to this type of tourism.

Previous studies have resulted in findings on the experiential dimensions of entertainment, aesthetics, education and escapism (Pine and Gilmore 1998). However, there is little research on the influence of experiential dimensions on the satisfaction and loyalty of camping tourists. To fill this gap, the purpose of this paper was to investigate the theoretical background and provide empirical evidence for the relationship between the dimensions of the tourism experience, and the satisfaction and loyalty of camping tourists. In accordance with the purpose of this research, specific goals have been set: (1) adapt and validate the measurement scale of the tourism experience in the context of camping tourism, (2) confirm the influence of certain dimensions of the tourism 
ToSEE - Tourism in Southern and Eastern Europe, Vol. 6, pp. 817-834, 2021.

T. Cegur Radović, D. Lončarić, J. Cvelić Bonifačić: CAMPING TOURISM EXPERIENCE ...

experience construct on the satisfaction of camping tourists, and (3) confirm the relationship between tourists' satisfaction and their loyalty.

The paper consists of five chapters. The introductory part, explaining the purpose and objectives of the research, is followed by a description of the basic concepts used in the paper, a description of the methodology, and the results of the empirical research. Discussion and conclusions of the research are given at the end of the paper.

\section{THEORETICAL FRAMEWORK}

\subsection{Characteristics of camping tourism}

Camping tourism is a form of nature-based special-interest tourism (Lee, 2020). It is one of the fastest growing segments in the tourism industry (O'Neill et al., 2010; Mikulić et al., 2017; Lee, 2020) and is changing significantly (Rogerson and Rogerson, 2020), but despite this it remains insufficiently researched by scientists. Camping tourists are ecologically responsible, they stay at a campsite and enjoy an active vacation that is characterized by the flexible, temporary and mobile nature of accommodation facilities, such as tents, campers and mobile houses, and by an inseparable connection with the natural surroundings (Blichfeldt and Mikkelsen 2015; Lee 2020). Brooker and Joppe (2014) define camping as a highly fragmented niche of the tourism sector. Camping tourism is seen as an activity which includes sleeping (one night minimum) in a recreational vehicle, camper, mobile house or some other type of temporary accommodation which substitutes the comfort of one's home (Brooker and Joppe 2014; Rogerson and Rogerson 2020). Camping has recently become more of a life-style, reflecting freedom, enjoyment in nature, socializing with friends, relatives and acquaintances, without sacrificing the comfort of the home. Mobile homes have started a revolution as a new type of camp accommodation, and they have brought about the transformation of camping into glamping (Milohnić et al. 2019). The results of a study conducted by Vrtodušić Hrgović et al. (2018) show that glamping accommodation is mainly considered to be a treehouse or some other unusual form of accommodation, and comfortable tents. Travelling for camping and the camping industry itself are a strong factor of the European economy. In Croatia, mobile homes of innovative design have become a new tourism product in campsites, a product closely linked to innovations and glamping accommodation.

\subsection{Tourism Experience}

Experiences are subjective, quite personal and intangible phenomena (O'Dell and Billing 2005) which are difficult to define (Coelho et al. 2018). The word "experience" denotes all types of things a person has achieved, regardless of their mental, emotional or other importance (Aho 2001). Some twenty years ago, Pine and Gilmore (1998) were the first to write about the experience economy. The term "consumer experience" related to providing excellent customer service (Pine and Gilmore 2013). Additional value is created by designing an experience, and the experience has greater value for the customer compared with the product or the service. 
ToSEE - Tourism in Southern and Eastern Europe, Vol. 6, pp. 817-834, 2021.

T. Cegur Radović, D. Lončarić, J. Cvelić Bonifačić: CAMPING TOURISM EXPERIENCE ...

In the tourism and hospitality sector, selling services no longer guarantees business success. It is necessary to gain a competitive advantage by creating and selling a fun unforgettable experience with added value (Pine and Gilmore 2002; Huang et al. 2016). The tourism experience plays a key role in tourism and leisure (Lončarić et al. 2018) and results from an interactive, intrapersonal communication between the experience provider and the tourist (da Costa Mendes et al. 2010, Lončarić et al. 2019). The tourism experience is defined as an interaction between the tourist and the destination; the tourists are actors, and the destination is the stage (Stamboulis and Skayannis 2003). It can be concluded that tourism experience is quite a personal phenomenon, consisting of different dimensions resulting from the interaction between the tourist and the destination.

In addition to the experience economy (Pine and Gilmore 1998) and experience marketing (Schmitt 1999), the possibility to conceptualize and apply the term "experience" in various areas has been the subject of many studies (Jensen et al. 2015). Over the past twenty years, research related to the tourism experience has focused on defining the tourism experience (Palmer 2005; Trauer and Ryan 2005; Larsen 2007), the dimensions of the tourism experience (Pine and Gilmore 1998; Uriely et al. 2002; White and White 2004, Ali et al. 2016) and the conceptual models of the tourism experience (Cohen, 2004; O'Dell, 2007; Cutler and Carmichael, 2010; Chang et al. 2014; Prebensen, 2014; Lee et al. 2015, 2015a,b, 2016, 2017, 2019; Tan 2017; Xu 2018; Lin and Lee 2019; Agapito 2020; Suhartanto et al. 2020; Zhang and Walsh 2020). The work of Pine and Gilmore was followed by other studies focused on the experience concept in the field of tourism (Oh et al. 2007; Hosany and Witham 2010; Mehmetoglu and Engen 2011; Lee et al. 2015, Lin and Lee 2019).

\subsection{Satisfaction and loyalty}

Customer experience has been defined as a psychological state occurring after the consumption of a product or services (Huang et al., 2016). Satisfaction in tourism has been defined as a function of pre-travel expectation and post-travel experience (Chen and Chen 2010). It is the result of an emotional reaction to a provided service (Havlena and Holbrook 1986; Russel 1980; Brunner-Sperdin 2012). Three categories of tourism satisfaction have been defined: satisfaction with service and experience during the travel, satisfaction with the destination, and satisfaction with the tourism experience (Chan et al. 2015). Many studies have concluded that a tourism experience precedes satisfaction (Triantafillidou and Petala 2015). The satisfaction of tourists is positively related to the quality of the tourism experience (Tribe and Snaith 1998; Lee and Chang 2012) and has a crucial impact on loyalty (Chen and Chen 2010; Osman and Sentosa 2013; Kastenholz et al. 2018; Gohary et al. 2020; Suhartanto et al. 2020). Tourist satisfaction is a guarantee of the destination's long-term sustainability (Gidey and Sharma 2017; Gebreegziabher and Kumar 2019).

Satisfaction is closely linked to customer loyalty. Copeland (1923) was the first to define customer loyalty and since then more than 200 definitions of loyalty have been coined (Zhang and Walsh 2020). In the past three decades, the concept of customer loyalty has 
ToSEE - Tourism in Southern and Eastern Europe, Vol. 6, pp. 817-834, 2021.

T. Cegur Radović, D. Lončarić, J. Cvelić Bonifačić: CAMPING TOURISM EXPERIENCE ...

started to be used in tourism also (Mazanec 2000; Jang and Feng 2007, Zhang and Walsh 2020). The loyalty of tourists to a destination is an important factor for the destination in gaining a competitive advantage (Suhartanto et al. 2020). The tourism literature clearly indicates that destination loyalty is an imperative factor in the development of the tourism industry (Zhang et al. 2014; Sirakaya-Turk et al. 2015; Suhartanto et al. 2015; 97). The fast expansion of social networks encourages tourists to increasingly share their experiences and look for tourism information online. The three variables used for measuring tourist loyalty are: revisit, positive word-of-mouth, and recommendations (Moise et al. 2018; Zhang and Walsh 2020). It can be concluded that tourists who are satisfied with a tourist destination will most likely recommend it to others and become loyal to the destination, visiting it for many years after. There is a strong link between a tourism experience and tourists' satisfaction with and loyalty to a certain destination. To provide a complete tourism experience in campsites, it is necessary to ensure a satisfactory stay for camping tourists, which will influence their loyalty to the camp. Hardy et al. (2005) proved that the tourists' level of satisfaction with a campsite affects their loyalty to the campsite.

\subsection{Research hypotheses}

Pine and Gilmore (1999) operationalized the tourism experience through four unique dimensions: aesthetics, education, entertainment and escapism. Schmitt (1999, 2011) divided the tourism experience into five experiential modules: sense, feel, think, act and relate. Cutler and Carmichael (2010) suggested that the tourism experience consists of the following dimensions: knowledge, perception, emotions, memories and selfachievement (Chiu and Cho 2020). Xu et al. (2018) used two dimensions of the tourism experience: the experience of nature and environment, and the experience of managing facilities in eco-tourism. Most authors have accepted Pine and Gilmore's dimensions of the tourism experience (Schmitt 1999; Oh, 2007; Mehmetoglu and Eugen 2011; Tan 2017; Ali et al. 2016; Lee et al. 2015, 2015a,b, 2016, 2019). The dimensions of the tourism experience differ from author to author also depending on the area of the study. Based on the above, a study hypothesis can be proposed: H1: The tourism experience of camping tourists is a multi-dimensional construct.

Tourism studies have proven that the experience of individuals affects their attitude, satisfaction, loyalty and behavioral intentions (Chang 2018; Hwang and Han 2018; Lin and Lee 2019). The most important experience is the one happening on-site, which has a positive effect on the tourists' satisfaction and loyalty (Hosany and Witham 2010, Lee and Chang 2012; Lee et al. 2015) as well as on their behavior in a destination (Cetin and Bilgihan 2016). The tourists' positive experience in utilizing destination services and other tourist resources could foster repeat visits and positive word-of-mouth to friends and relatives (Bramwell 1998; Oliver 1999; Kozak and Rimmington 2000; Yoon and Uysal 2005; Kim et al. 2010; Song et al. 2012; Agyeiwaah et al. 2016; Agyeiwaah et al. 2018). The four dimensions of tourism experience influence tourists' emotions which develop tourist satisfaction (Ali et al. 2016). Based on the above, the following research hypothesis can be proposed: H2: There is a positive relationship between the dimensions of the tourism experience and the satisfaction of a camping tourist. 
ToSEE - Tourism in Southern and Eastern Europe, Vol. 6, pp. 817-834, 2021.

T. Cegur Radović, D. Lončarić, J. Cvelić Bonifačić: CAMPING TOURISM EXPERIENCE

One of the dimensions of a tourism experience is education, which appears when an individual learns new terminology during certain activities (Pine and Gilmore 1999). The experience of education in tourism is acquired when tourists gain additional know-how, for example, by taking educational workshops where a tourist participates more actively than passively (Tan 2017). The experience of education is seen as active tourist participation in a certain destination (Oh et al. 2007). The tourists' active participation in education increases their satisfaction and loyalty to a certain destination. Based on the results of correlation analysis, a study on the dimensions of tourism experience in rural tourism proves that aesthetics and education boost high levels of satisfaction and excitement in rural tourists (Kastenholz et al. 2017). Also, the results of a study involving rock concert visitors prove that education is an important dimension of the tourism experience for visitor satisfaction (Kübra and Kerem 2020). In view of the above, the following hypothesis can be proposed: H2a: There is a positive relationship between education and the satisfaction of a camping tourist.

Escapism, as a dimension of the tourism experience, implies active tourist participation in a given destination (Oh et al. 2007). It reflects to what extent tourists immerse themselves in the natural environment and disturb the psychological natural environment (Hosany and Witham 2010). Escapism is one of the dimensions of a tourism experience, which has a positive effect on the satisfaction of a festival visitor (Mehmetoglu and Engen 2011), and on satisfaction with an experience in nature (Sotiriadis 2017). Taking into account the above mentioned, the following hypothesis can be proposed $H 2 b$ : There is a positive relationship between escapism and the satisfaction of camping tourists.

Aesthetics includes the way tourists immerse themselves in the natural environment and interpret the physical surrounding based on nature (Hosany and Witham, 2010). The aesthetic experience is achieved when tourists enjoy and passively appreciate that they are staying in a destination (Oh et al. 2007; Tan 2017). Aesthetics in rural tourism is highlighted as an area with the most features, and together with the education dimension, has the highest correlation level with tourist satisfaction (Kastenholz et al. 2017). The results of a study on the relationship between aesthetics and satisfaction with a rock concert show that the aesthetic experiences of a concert visitor are transformed into the visitor's satisfaction with the concert, thus proving that aesthetics is a very dominant dimension of a tourism experience (Kübra and Kerem 2020). Furthermore, a study conducted in an art museum in Italy also suggests the dominance of aesthetics (Vesci et al. 2020). Therefore, the following hypothesis can be proposed $H 2 c$ : There is a positive relationship between aesthetics and the satisfaction of a camping tourist.

The experience of entertainment is achieved when tourists passively observe the activities taking place in a destination. Their relationship to an event is more of absorption than active participation (Tan 2017). The tourist who passively participates in the activities of a destination does not influence the activities of the destination directly, whereas an active participant personally influences the event which becomes a part of his or her experience (Pine and Gilmore, 1999). The findings of a study on the visitors of a rock concert prove that entertainment is a tourism experience dimension that is important for the visitors' satisfaction (Kübra and Kerem 2020). A study by Ali et al. (2016) also indicates that entertainment is the main determinant of customer emotions which develop tourist satisfaction in Malaysian resort hotels. Therefore, the following 
ToSEE - Tourism in Southern and Eastern Europe, Vol. 6, pp. 817-834, 2021.

T. Cegur Radović, D. Lončarić, J. Cvelić Bonifačić: CAMPING TOURISM EXPERIENCE ...

hypothesis can be proposed $H 2 d$ : There is a positive relationship between entertainment and the satisfaction of a camping tourist.

Tourist satisfaction is considered to affect a tourist's behavioural intention (Costa Mendez et al. 2010, Lončarić et al. 2018). In fact, when customers remember their past positive experience of an event or a destination, it is probable they will spread positive word-of-mouth and continue revisiting that event or destination as a sign of loyalty (Thomsen and Hansen 2009; Manthiou 2016). Therefore, if tourists are satisfied, their intent will be to revisit the destination in the future (Kozak and Rimmington 2000; Hui et al. 2007; Lončarić et al. 2018; Hutchinson et al. 2009; Kim et al. 2015). A satisfactory tourism experience can affect post-visit behavioural intentions, such as the intention to return to a destination (Chen and Tsai 2007) and the willingness to recommend it (De Nisco et al. 2015). The above-stated presents arguments for proposing hypothesis H3: There is a positive relationship between the satisfaction of a camping tourist and loyalty.

The proposed hypotheses have been verified, with empirical research explained below.

\section{RESEARCH METHODOLOGY}

\subsection{Measurement scales}

To achieve the purpose and goals of the paper, an empirical study was conducted on a convenience sample of respondents $(\mathrm{N}=143)$. Scales from previous studies were used. They were translated into Croatian and adapted to camping tourism, which is why it was necessary to validate the measurement instrument. Before conducting empirical research, a structured questionnaire was designed and its content was validated by experts and then adapted in compliance with their reviews. The content validity of the survey instrument was then tested in June 2018 on a sample of 13 students with experience in camping tourism. The comments within the framework for evaluating the content validity of the questionnaire referred to the used terminology and its clarity. The respondents gave recommendations on how to improve the questionnaire, upon which another version of the questionnaire was developed and used in further research. The attitudes of the respondents were measured using a Likert scale for evaluating attitudes, ranging from 1 to 7 ( 1 - completely disagree, 7 - completely agree). The tourism experience was measured using the tourist recreation experience scale created by Hosany and Witham (2010) and comprising four dimensions and 14 variables. The tourism experience consisted of the following dimensions: aesthetics (4 variables), entertainment (3 variables), education (3 variables), and escapism (4 variables). The satisfaction of the camping tourist was measured using the tourist satisfaction scale by Han, Lee and Hwang (2016), which consists of three items. The loyalty of tourists was measured using three items taken from a paper by Pan (2018). The construct and the accompanying variables are shown in Table 1. 
ToSEE - Tourism in Southern and Eastern Europe, Vol. 6, pp. 817-834, 2021.

T. Cegur Radović, D. Lončarić, J. Cvelić Bonifačić: CAMPING TOURISM EXPERIENCE ...

\section{Table 1: Constructs and variables}

\begin{tabular}{|c|c|c|}
\hline Construct & $\begin{array}{l}\text { Item } \\
\text { number }\end{array}$ & Item \\
\hline \multirow{14}{*}{$\begin{array}{l}\text { TOURISM } \\
\text { EXPERIENCE }\end{array}$} & TE1 & The setting of the campsite was attractive. \\
\hline & TE2 & The setting of the campsite plays close attention to design details. \\
\hline & TE3 & I felt comfortable staying in the campsite. \\
\hline & TE4 & I felt a real sense of harmony. \\
\hline & TE5 & The campsite activities were interesting. \\
\hline & TE6 & The campsite activities were amazing. \\
\hline & TE7 & The campsite activities were entertaining. \\
\hline & TE8 & The experience in the campsite made me more knowledgeable. \\
\hline & TE9 & It was a real learning experience. \\
\hline & TE10 & It stimulated my curiosity to learn new things. \\
\hline & TE11 & I felt I played a different character here. \\
\hline & TE12 & The experience let me imagine being somewhere else. \\
\hline & TE13 & I completely escaped from my daily routine. \\
\hline & TE14 & I felt I was in a different time or place. \\
\hline \multirow{3}{*}{ SATISFACTION } & $\mathrm{S} 1$ & I am delighted with this campsite. \\
\hline & $\mathrm{S} 2$ & In overall I am satisfied with this campsite. \\
\hline & $\mathrm{S} 3$ & My satisfaction with this campsite exceeds my expectations. \\
\hline \multirow{3}{*}{ LOYALTY } & L1 & $\begin{array}{l}\text { I will positively evaluate this campsite to my friends and relatives as } \\
\text { well as other people. }\end{array}$ \\
\hline & $\mathrm{L} 2$ & I will revisit this campsite in the future. \\
\hline & L3 & $\begin{array}{l}\text { I will recommend this campsite to my friends and relatives as well as } \\
\text { other people. }\end{array}$ \\
\hline
\end{tabular}

Source: Authors'

\subsection{Data collection and sample}

The data were collected from 143 respondents who had stayed in Croatian campsites sometime during the past two years. The questionnaires were handed out to the respondents and were completed using the paper and pencil method. A total of 140 valid questionnaires were collected. Table 2 shows the sample description based on gender, age, main reasons for coming to the campsite, and characteristics of staying at the campsite. The questions provided multiple answer options.

Table 2: Sample structure $(\mathbf{N}=\mathbf{1 4 0})$

\begin{tabular}{lrr}
\hline Characteristics & Total \\
\cline { 2 - 3 } Gender & $\mathrm{N}$ & $\%$ \\
Female & 64 & 51.2 \\
Male & 61 & 48.8 \\
Age & & \\
$18-25$ & 39 & 27.9 \\
$26-35$ & 47 & 33.6 \\
$36-45$ & 21 & 15.0 \\
$46-55$ & 14 & 10.0 \\
$56-65$ & 9 & 6.4 \\
Over 66 & 10 & 7.1 \\
\hline
\end{tabular}


ToSEE - Tourism in Southern and Eastern Europe, Vol. 6, pp. 817-834, 2021.

T. Cegur Radović, D. Lončarić, J. Cvelić Bonifačić: CAMPING TOURISM EXPERIENCE ...

Table 2 (continued)

\begin{tabular}{|c|c|c|}
\hline \multirow{2}{*}{ Characteristics } & \multicolumn{2}{|c|}{ Total } \\
\hline & $\mathrm{N}$ & $\%$ \\
\hline \multicolumn{3}{|l|}{ The main motive for arrival } \\
\hline rest and relaxation & 123 & 87.9 \\
\hline new experiences & 40 & 28.6 \\
\hline fun & 39 & 27.9 \\
\hline gastronomic offer & 3 & 2.1 \\
\hline the beauty of nature and landscape & 87 & 62.1 \\
\hline sports and recreation & 41 & 29.3 \\
\hline health & 9 & 6.4 \\
\hline something else & 8 & 5.7 \\
\hline \multicolumn{3}{|l|}{ Travel partners } \\
\hline go alone & 8 & 5.7 \\
\hline partner & 34 & 24.3 \\
\hline family (with children) & 55 & 39.3 \\
\hline friends/colleagues & 59 & 42.1 \\
\hline organised group of people & 10 & 7.1 \\
\hline \multicolumn{3}{|l|}{ Length of stay } \\
\hline 1 day & 7 & 5.0 \\
\hline 2-3 days & 32 & 22.9 \\
\hline 4-7 days & 62 & 44.3 \\
\hline more than 7 days & 40 & 28.6 \\
\hline \multicolumn{3}{|l|}{ Number of previous visit } \\
\hline This is my first time & 46 & 32,9 \\
\hline Only once before & 31 & 22.1 \\
\hline Two or more visits before & 41 & 29.3 \\
\hline I have been visiting for a long time & 22 & 15.7 \\
\hline \multicolumn{3}{|l|}{ Activities in campsite } \\
\hline swimming & 114 & 81.4 \\
\hline walking/day hiking & 108 & 77.1 \\
\hline photography & 66 & 47.1 \\
\hline cycling & 56 & 40.0 \\
\hline mountain climbing & 51 & 36.4 \\
\hline picnicking & 45 & 32.1 \\
\hline boating & 31 & 22.1 \\
\hline
\end{tabular}

Source: Research results

An analysis of the sample structure shows that more women (51.2\%) than men (48.8\%) participated in the survey. Concerning the age structure, the respondents were mainly younger people, between 18 and 36 years of age (61.4\%). The reason for this is that younger respondents tended to complete the survey, compared with the older population. All of the respondents were from Croatia. The main reason for coming to the campsites was vacation/relaxation ( $87.9 \%$ ), followed by the beauty of nature and the environment $(62.1 \%)$, sport and recreation $(29.3 \%)$, new experiences and events (28.6\%), entertainment $(27.9 \%)$, health $(6.4 \%)$, food $(2.4 \%)$ and other reasons $(5.7 \%)$. The respondents came to the campsite with friends and acquaintances $(42.1 \%)$, with family members $(39.3 \%)$, with a partner $(24.3 \%)$, with an organised group of people $(7.1 \%)$ and alone $(5.7 \%)$. Most of the respondents $(44.3 \%)$ stayed in the campsite 4-7 days, or 7 days and more $(28.6 \%)$. One third of the respondents $(32.9 \%)$ visited the campsite for the first time. Slightly fewer respondents $(29.3 \%)$ visited the campsite two or more times, and $22.1 \%$ had been to the campsite once before. A total of 15.7 respondents have been visiting the campsites for many years. An analysis of the recreational activities of tourists 
ToSEE - Tourism in Southern and Eastern Europe, Vol. 6, pp. 817-834, 2021.

T. Cegur Radović, D. Lončarić, J. Cvelić Bonifačić: CAMPING TOURISM EXPERIENCE ...

during their stay in the campsite confirms that the majority of the respondents mainly like to swim (81.4\%), and walk/day hike $(77.1 \%)$, depending on whether they are staying on the coast or inland. Other activities they engage in during their stay in the campsites include photography $(47.1 \%)$, cycling $(40 \%)$, hiking $(36.4 \%)$, picnics in nature $(32.1 \%)$, boating $(22.1 \%)$ and other activities in smaller percentages.

\section{FINDINGS}

The data analysis included a descriptive statistical analysis of the constructs - tourism experience, satisfaction of camping tourists, and loyalty - as well as a reliability analysis and dimensionality of the measurement scales. The descriptive analysis of all constructs was done first (tourism experience, satisfaction of camping tourists and loyalty). Exploratory factor analysis was conducted to determine the dimensionality of the measurement scales. The reliability of the measuring instrument was confirmed by applying the indicators of internal consistency (Cronbach's alpha).

\subsection{Descriptive analysis}

To begin with, descriptive analysis was conducted of the variables of the constructs of tourism experience, camping tourist satisfaction, and camping tourist loyalty (Table 3 ).

Table 3: Descriptive statistics of variables

\begin{tabular}{lcccc}
\hline Item number & Arithmetic mean & Mode & Standard deviation & Asymmetry coefficient \\
\hline TE1 & 5.56 & 5 & 1.21 & -0.71 \\
TE2 & 4.49 & 5 & 1.58 & -0.19 \\
TE3 & 5.78 & 6 & 1.12 & -0.80 \\
TE4 & 5.23 & 5 & 1.36 & -0.63 \\
TE5 & 4.79 & 5 & 1.51 & -0.33 \\
TE6 & 3.95 & 5 & 1.54 & -0.07 \\
TE7 & 4.47 & 5 & 1.66 & -0.46 \\
TE8 & 4.82 & 5 & 1.65 & -0.47 \\
TE9 & 4.40 & 4 & 1.60 & -0.14 \\
TE10 & 4.30 & 5 & 1.63 & -0.26 \\
TE11 & 4 & 1.82 & -0.14 \\
TE12 & 3.54 & 1 & 1.89 & -0.16 \\
TE13 & 3.46 & 7 & 1.57 & -1.28 \\
TE14 & 7.69 & 7 & 1.84 & -0.67 \\
S1 & 4.89 & 4 & 1.40 & -0.30 \\
S2 & 5.98 & 5 & 1.26 & -0.56 \\
S3 & 5.21 & 4 & 1.46 & -0.29 \\
L1 & 4.40 & 6 & 1.35 & -0.89 \\
L2 & 5.49 & 6 & 1.63 & -0.21 \\
L3 & 5.04 & 6 & 1.41 & -1.06 \\
\hline
\end{tabular}

Source: Research results

The arithmetic means of the variables of the tourism experience construct (TE) range from 3.46 to 5.78. Variable TE12, "The experience let me imagine being somewhere else", has the lowest score, while the variable TE3, "I felt comfortable staying in the 
ToSEE - Tourism in Southern and Eastern Europe, Vol. 6, pp. 817-834, 2021.

T. Cegur Radović, D. Lončarić, J. Cvelić Bonifačić: CAMPING TOURISM EXPERIENCE ...

campsite." has the highest. The mode ranges between 1 and 7 . The TE12 variable has the lowest arithmetic mean and mode 1 . The values of the standard deviation exceed 1 , pointing to data dispersion. The asymmetry coefficients for all variables are in the interval from -1 to +1 , which points to a normal distribution, except for the variable TE13, "I completely escaped from my daily routine", which shows moderate negative asymmetry. The values of the arithmetic mean with regard to the constructs the satisfaction of the camping tourists (S) range from 4.40 to 5.21. The variable S3, "My satisfaction with this campsite exceeds my expectations." has the lowest value, and the variable S2, "Overall, I am satisfied with this campsite." has the highest. The mode ranges from 4 to 5 . The values of the standard deviation exceed 1, pointing to data dispersion. The asymmetry coefficients for all variables are in the interval from -1 to +1 , pointing to normal distribution. The arithmetic means of the variables of the loyalty to the stay in the campsite construct (L) range from 5.04 to 5.49. The variable L2, "I will revisit this campsite in the future." has the lowest value and the variable L1, "I will give a positive evaluation of this campsite to my friends and relatives as well as other people" has the highest. All the modes are 6 . The values of the standard deviation exceed 1 , pointing to data dispersion. The asymmetry coefficients for all variables are in the interval from -1 to +1 , pointing to normal distribution, except for the variable L3, "I will recommend this campsite to my friends and relatives as well as other people", which shows moderate negative asymmetry.

\subsection{Validation of the measurement scales}

To determine the validity of the research instrument, an analysis of the dimensionality and reliability of the measurement scales was performed. The reliability of the measurement scales was confirmed by applying the coefficient of internal consistency, Cronbach's alpha. For the measurement scale of the tourism experience, dimensionality analysis was conducted using exploratory factor analysis. The first step includes assessing the adequacy of the sample by calculating the Kaiser-Meyer-Olkin (KMO) coefficient and Bartlett's test of sphericity. Sampling adequacy measured by KMO was assessed for the purpose of evaluating whether the data fit well with the factors (Field 2005), and has values from 0 to 1 . In order for the factor analysis to be suitable, the value of this index has to be over 0.5 (Rozga 2010). The values between 0.5 and 0.7 are acceptable; the values between 0.7 and 0.8 are good, and the values between 0.8 and 0.9 are excellent (Field, 2005). The results show that the adequacy measures of the tourist experience construct are appropriate (KMO is 0.783 , and Bartlett's test of sphericity $\left(\chi^{2}\right.$ $=1.285,50 ; \mathrm{p}<0,001)$. It can be concluded that the correlation matrix is acceptable for conducting exploratory factor analysis based on the recommendations (Tabachnik and Fidell 2007; 614). Principal component analysis with varimax rotation of the factor axis was carried out. The varimax method of the rotation was used since the goal was to reduce the variables to a smaller number of factors (Hair et al. 2006; 126-127) while maximizing the percentage of explained variance. The criteria for the number of extracted factors and the preserved variables are based on eigenvalues, the percentage of the explained variance, and significance of the factor loadings. Factors with eigenvalues over 1 , factors with a total of $60 \%$ of the explained variance, and factors with loading above 0.05 , taking into consideration the number of the respondents, are acceptable (Hair 2014; 115). 
ToSEE - Tourism in Southern and Eastern Europe, Vol. 6, pp. 817-834, 2021.

T. Cegur Radović, D. Lončarić, J. Cvelić Bonifačić: CAMPING TOURISM EXPERIENCE ...

Table 4 shows that four factors were extracted using exploratory factor analysis for the tourism experience construct. Total percentage of the explained variance shows that the extracted factors contain $75.972 \%$ of information of all variables. This is a high percentage and points to a good relationship among the variables. The eigenvalue of each extracted factor is over 1. Based on these results, it is clear that the criteria for determining the number of extracted factors have been met. The factor loadings for all factors are positive. All factor loadings exceed 0.50, which is considered high loading. Table 4 lists the factors in order of importance. The percentage of the explained variance shows how successfully each factor explains the contained variables. The values range from $7.948 \%$ to $38.489 \%$. The number of variables in each factor is between 3 and 4 . Factor 1 is called escapism; it contains four variables and explains $38.489 \%$ of variance. Factor 2 is called aesthetics. It contains four variables, which explains $18.162 \%$ of variance. Factor 3 is called entertainment; it contains three variables and explains $11.373 \%$ of variance Factor 4 is called education; it contains three variables and explains $7.948 \%$ of variance.

Table 4: Exploratory factor analysis of the tourism experience construct

\begin{tabular}{|c|c|c|c|c|}
\hline $\begin{array}{l}\text { Item } \\
\text { number }\end{array}$ & Variable & $\begin{array}{l}\text { Factor } \\
\text { loadings }\end{array}$ & $\begin{array}{l}\text { Total variance } \\
\text { explained }(\%)\end{array}$ & $\begin{array}{l}\text { Cronbach } \\
\text { alpha }\end{array}$ \\
\hline \multicolumn{3}{|c|}{ FACTOR 1 - ESCAPISM } & 38.489 & 0.849 \\
\hline TE11 & I felt I played a different character here. & .877 & & \\
\hline TE12 & $\begin{array}{l}\text { The experience let me imagine being } \\
\text { somewhere else. }\end{array}$ & .836 & & \\
\hline TE14 & I felt I was in a different time or place. & .806 & & \\
\hline TE13 & I completely escaped from my daily routine. & .721 & & \\
\hline \multicolumn{3}{|c|}{ FACTOR 2 - AESTHETICS } & 18.162 & 0.804 \\
\hline TE4 & I felt a real sense of harmony. & .813 & & \\
\hline TE3 & I felt comfortable staying in the campsite. & .778 & & \\
\hline TE1 & The setting of the campsite was attractive. & .770 & & \\
\hline TE2 & $\begin{array}{l}\text { The setting of the campsite plays close } \\
\text { attention to design details. }\end{array}$ & .669 & & \\
\hline \multicolumn{3}{|c|}{ FACTOR 3 - ENTERTAINMENT } & 11.373 & 0.914 \\
\hline TE7 & The campsite activities were entertaining. & .891 & & \\
\hline TE5 & The campsite activities were interesting. & .864 & & \\
\hline TE6 & The campsite activities were amazing. & .852 & & \\
\hline \multicolumn{3}{|c|}{ FACTOR 4 - EDUCATION } & 7.948 & 0.887 \\
\hline TE9 & It was a real learning experience. & .885 & & \\
\hline TE8 & $\begin{array}{l}\text { The experience in the campsite made me } \\
\text { more knowledgeable. }\end{array}$ & .864 & & \\
\hline TE10 & It stimulated my curiosity to learn new things. & .798 & & \\
\hline
\end{tabular}

Source: Research results

Following exploratory factor analysis, reliability analysis of the measurement scale was also conducted using the Cronbach alpha coefficient, which should provide values between 0 and 1 . The closer the coefficient is to the value 1 , the more reliable is the measurement scale. The lowest suggested value of the coefficient is 0.6 , whereas values of 0.7 and over are considered good (Peterson 1994). Cronbach's alpha coefficients for the tourist experience construct are in the range from 0.804 to 0.914 . 
ToSEE - Tourism in Southern and Eastern Europe, Vol. 6, pp. 817-834, 2021.

T. Cegur Radović, D. Lončarić, J. Cvelić Bonifačić: CAMPING TOURISM EXPERIENCE ...

Reliability analysis was conducted as the construct concerning the tourists' satisfaction with the stay in the campsite and their loyalty are measured with three items each. The Cronbach alpha coefficients obtained for the camping tourist satisfaction construct and the loyalty construct were 0.880 and 0.895 , respectively. The coefficients point to high reliability of the measurement scales (Peterson 1994).

After the measurement scales were validated, the set hypotheses were tested. Multiple regression analysis was applied to determine the influence of the dimensions of the tourism experience construct on camping tourist satisfaction. The dimensions of the tourism experience were formed as linear composites of the variables in compliance with the results of the factor analysis, and they were treated as independent variables in the model, whereas camping tourist satisfaction was observed as a dependent variable. The results are shown in Table 5.

\section{Table 5: Multiple regression analysis for variables predicting satisfaction of camping tourists}

\begin{tabular}{lrrrrr}
\hline Independent variables & $\mathrm{B}$ & Std. Error & Beta & $\mathrm{t}$ & Sig. \\
\hline (Constant) & -.896 & 1.073 & & -.835 & .405 \\
ESCAPISM & .126 & .037 & .200 & 3.443 & .001 \\
ESTHETIC & .471 & .056 & .531 & 8.329 & .000 \\
ENTERTAINMENT & .250 & .057 & .284 & 4.401 & .000 \\
EDUCATION & .006 & .054 & .007 & .118 & .906 \\
R2 & 0.646 & & & \\
Adjusted R2 & 0.635 & & & \\
Standard error & 2.26528 & & & \\
F ratio & 58.856 & & & \\
Significance & 0.000 & & & & \\
\hline
\end{tabular}

Source: Research results

The results of the regression analysis are statistically significant $(\mathrm{F}=58.856, \mathrm{p}=0.000)$, the determination coefficient $\left(\mathrm{R}^{2}\right)$ totals 0.646 , and the variables in the model share $64.6 \%$ of the common factors, which means that $64.6 \%$ of the variances in the camping tourist satisfaction construct can be predicted with the dimensions of the tourism experience. The analysis confirms that the dimensions of the tourism experience "escapism" $(\beta=0.200, p=0.001)$, "aesthetics" $(\beta=0.531, p=0.000)$ and "entertainment" $(\beta=0.284, p=0.000)$ have a considerable impact on the camping tourists' satisfaction and loyalty. The "education" dimension $(\beta=0.007, \mathrm{p}=0.906)$ does not have a significant influence on the camping tourist satisfaction. To confirm the relationship between camping tourist satisfaction and loyalty, a correlation analysis was conducted using the Pearson correlation coefficient. A statistically significant positive relation between camping tourist satisfaction and loyalty was established $(r=0.763, \mathrm{p}=0.000)$.

\section{DISCUSSION AND CONCLUSION}

The purpose of this research is to establish a relationship between the dimensions of tourists' camping experience, and their satisfaction and loyalty. To achieve this goal, three hypotheses were set. A measuring instrument was designed and empirical research was carried out, which has resulted in important findings. 
ToSEE - Tourism in Southern and Eastern Europe, Vol. 6, pp. 817-834, 2021.

T. Cegur Radović, D. Lončarić, J. Cvelić Bonifačić: CAMPING TOURISM EXPERIENCE

The scale for measuring the tourism experience was adapted to measuring the experience of camping tourists, and its reliability and dimensionality were verified. The results confirmed the validity of the scale for its application in the context of camping tourism. It has been established that the tourism experience of a camping tourist is a multidimensional construct, consisting of four dimensions: escapism, aesthetics, entertainment, and education. This confirms the first hypothesis $H 1$, and the results are in compliance with research by Pine and Gilmore (1999).

Furthermore, the influence of the tourism experience dimension on the satisfaction of the camping tourist was analysed. Multiple regression analysis confirmed the statistical significance and positive influence of the escapism, aesthetics and entertainment dimensions of the tourism experience, confirming the hypotheses $\mathrm{H} 2 b, \mathrm{H} 2 \mathrm{c}, \mathrm{H} 2 \mathrm{~d}$. It was also confirmed that the dimension of aesthetics has the biggest influence on the satisfaction of the camping tourist. The influence of the education dimension on the satisfaction of the camping tourist was not confirmed. Therefore, $H 2 a$ hypothesis is discarded. This means that $H 2$ hypothesis can be considered confirmed. The results are in line with a study by Sotiriadis (2017) which proved, on the example of nature-based tourism, that the dimensions of escapism and aesthetics influence tourist satisfaction.

Oh et al. (2007) proved that aesthetics affects satisfaction with the bed \& breakfast accommodation, whereas escapism and entertainment do not affect satisfaction with the stay. The satisfaction of the festival visitors is mainly influenced by escapism and aesthetics, whereas education and entertainment do not have an influence (Mehmetoglu and Engen 2011).

The empirical research established a statistically significant positive relationship between the satisfaction of camping tourists and their loyalty to the camp, which is confirmed by the $\mathrm{H} 3$ hypothesis. This finding is not surprising, since many studies $\mathrm{Wu}$ and Liang 2011; Osman and Sentosa, 2013; Anton et al. 2014; Hultman et al. 2015; Suhartanto et al., 2015; Choi and Cai 2016; Kim and Thapa 2018; Zhang and Walsh 2020; Lončarić et al. 2021) have confirmed the relationship between tourist satisfaction and loyalty.

This study has a theoretical and applicative contribution. In the theoretical sense, the contribution lies in the adaptation and validation of the scale for measuring the camping tourist experience, and verification of the influence of certain experience dimensions on tourists' satisfaction with and loyalty to campsites in which they achieved a specific experience. In a practical sense, this study provides information to campsite managers, which they could use to significantly improve service quality, with the aim of enhancing the tourism experience, and tourist satisfaction and loyalty. This study can help managers in tourism to create offerings, tourism products and services for various target groups of tourists, which will enhance their experience in campsites and lead to satisfaction with the stay and loyalty to a certain camp. New and innovative forms of accommodation, such as mobile houses and glamping tents of different shapes and materials, reinforce the experience of escapism and aesthetics of the campsites.

This study has certain limitations which should be mentioned. The main limitation refers to the study sample. It is a relatively small but suitable sample used for the purpose of validating the measuring scale. However, future studies should be carried out on larger 
ToSEE - Tourism in Southern and Eastern Europe, Vol. 6, pp. 817-834, 2021.

T. Cegur Radović, D. Lončarić, J. Cvelić Bonifačić: CAMPING TOURISM EXPERIENCE ...

samples of tourists staying in campsites during the time of the studies. Studies could also be conducted in various types of campsites, for example, campsites on the coast and campsites in continental Croatia. In addition to the mentioned constructs, future studies could investigate the influence of other constructs, such as place attachment, service quality, destination image, environmental attitudes and environmentally responsible behaviour. The studies should be conducted continuously to consistently monitor the satisfaction and loyalty of tourists during their stay in campsites.

\section{REFERENCES}

Aho, S.K. (2001), „Towards a general theory of touristic experiences: Modelling experience process in tourism“", Tourism Review, Vol. 56, No. 3-4, pp. 33-37.

Ali, F., Hussain, K., Omar, R. (2016), Diagnosing customers experience, emotions and satisfaction in Malaysian resort hotels, European Journal of Tourism Research, Vol. 12, pp. 25-40.

Agapito, D., Pinto, P., Passos Ascenção, M. and Tuominen, P. (2020), „Designing compelling accommodation escapes: Testing a framework in a rural context", Tourism and Hospitality Research, Vol. 21, No. 3, pp. 1-16. https://doi.org/10.1177/1467358420972753

Agyeiwaah, E., Otoo, F.E., Suntikul, W. and Huang, W.J. (2018), , Understanding culinary tourist motivation, experience, satisfaction, and loyalty using a structural approach“, Journal of Travel and Tourism Marketing, Vol. 36, No. 3, pp. 1-19. https://doi.org/10.1080/10548408.2018.1541775

Blichfeldt, B.S. and Mikkelsen, M.V. (2015), „Camping tourism“, in J. Jafari i H. Xiao (Eds.), Encyclopaedia of Tourism, (Living Edition), Dordrecht; Springer, pp.1-2.

Brooker, E. and Joppe, M. (2013), „Trends in Camping and Outdoor Hospitality - An International Review“, Journal of outdoor Recreation and Tourism, Vol. 3, pp. 1-6

Brooker, E. and Joppe, M. (2014), „A Critical Review of Camping Research and Direction for Future Studies“, Journal of Vacation Marketing, Vol. 20, No. 4, pp. 335-351

Brunner-Sperdin, A., Peters, M. and Strobl, A. (2012), „It is all about the emotional state: Managing tourists experiences“, International Journal of Hospitality Management, Vol. 31, No. 1, pp. 23-30. http://dx.doi.org/10.1016/j.ijhm.2011.03.004.

Buonincontri, P., Morvillo, A., Okumus, F. and van Niekerk, M. (2017), „Managing the experience co-creation process in tourism destinations: Empirical findings from Naples“, Tourism Management, Vol. 62, pp. 264-277. https://doi.org/10.1016/j.tourman. 2017.04.014

Cegur Radović, T. (2021), The interdependence of tourist experience and environmentally responsible behaviour of tourists in campsites, Doctoral Dissertation, Faculty of Tourism and Hospitality Management, Opatija.

Cegur Radović, T. (2021), The interdependence of tourist experience and environmentally responsible behaviour of tourists in campsites, Doctoral Dissertation Summary, Tourism and Hospitality Management, Vol. 27, No. 3, pp. 737-741.

Cetin, G. and Bilgihan, A. (2016), „Components of cultural tourists’ experiences in destinations“, Current Issues in Tourism, Vol. 19, No. 2, pp. 137-154. http://www.tandfonline.com/doi/full/10.1080/13683500.2014.994595.

Chang, L., Backman, K.F. and Huang, Y.C. (2014), „Creative tourism: a preliminary examination of creative tourists' motivation experience, perceived value and revisit intention", International Journal of Culture, Tourism and Hospitality Research, Vol. 8, No. 4, pp. 401-419.

Chen, C.F. and Chen, F.S. (2010), „Experience quality, perceived value, satisfaction and behavioural intentions for heritage tourists“, Tourism Management, Vol. 31, No. 1, pp. 29-35. http://dx.doi.org/10.1016/j.tourman.2009.02.008.

Chiu, W. and Cho, H. (2020), „Mapping aborigional tourism experience in Taiwan: A case of the Formosan Aboriginal Culture Village“, Journal of Vacation Marketing, Vol. 27, No. 1, pp. 1-15. https://doi.org/10.1177/1356766720950345

Coelho, M., Gosling, M. and Almeida, A. (2018), „Tourism experience: Core processes of memorable trips“, Journal of Hospitality and Tourism Management, Vol. 37, pp. 11-22. http://doi.org/10.1016/j.tourman.2018.08.004.

Cvelić Bonifačić, J, Milohnić, I. and Cerović, Z. (2017), „Glamping - Creative accommodation in camping resorts: insights and opportunities", in $4^{\text {th }}$ International Scientific Conference ToSEE - Tourism in 
ToSEE - Tourism in Southern and Eastern Europe, Vol. 6, pp. 817-834, 2021.

T. Cegur Radović, D. Lončarić, J. Cvelić Bonifačić: CAMPING TOURISM EXPERIENCE ...

Southern and Eastern Europe 2017; Tourism and Creative Industries: Trends and Challenges, Vol. 4, pp. 101-114.

De Nisco, A., Riviezzo, A. and Napolitano, M.R. (2015), “An Importance-Performance analysis of tourist satisfaction level: evidence from Campania (Italy)", European Journal of Tourism Research, Vol. 10, pp. 64-75.

Garst, B.A., Baughman, S. and Franz, N.K. (2013), „Strengthening Families: Exploring the Impacts of Family Camp Experiences on Family Functioning and Parenting“, Journal of Experiential Education, Vol. 36, No. 1 , pp. 65-77.

Gebreegziabher, A.A. and Kumar, S. (2019), „The structural relationship between tourist satisfaction and sustainable heritage tourism in Tigrai“, Ethiopia, Heliyon, Vol. 5, pp. 1-31, https://doi.org/10.1016/j.heliyon.2019

Gračan, D. and Birin, A. (2013), ,The implementation of ecological standards in sustainable development offer of Croatian camps", in 2nd International Scientific Conference ToSEE - Tourism in South East Europe 2013; Crisis - a Challenge of Sustainable Tourism Development?, Vol. 2, pp. 131-143.

Hosany, S. and Witham, M. (2010), "Dimensions of Cruisers' Experiences, Satisfaction and Intention to Recommend", Journal of Travel Research, Vol. 49, No. 3, pp. 351-364.

Huang, S., Afsharifar, A. and van der Veen, R. (2016), „Examining the moderating role of prior knowledge in the relationship between destination experiences and tourist satisfaction", Journal of Vacation Marketing, Vol. 22, No. 4, pp. 320-334. http://journals.sagepub.com/doi/10.1177/1356766715618996.

Ivandić, N. (2006), Trendovi ljetnog odmorišnog turizmau svijetu i u Europi, Institut za turizam, Zagreb.

Jensen, Ø., Lindberg, F. and Østergaard, P. (2015), „How Can Consumer Research Contribute to Increased Understanding of Tourist Experiences? A Conceptual Review“, Scandinavian Journal of Hospitality and Tourism, Vol. 15, Sup.1, pp. 9-27. https://doi.org/10.1080/15022250.2015.1065591

Kastenholz, E., Carneiro, M.J., Marques, C.P. and Loureiro, S.M.C. (2017), The dimensions of rural tourism experience: impacts on arousal, memory and satisfaction, Journal of Travel and Tourism Marketing, Vol. 35, No. 2, pp. 189-201. https://doi.org/10.1081/10548408.2017.1350617

Kim, M. and Thapa, B. (2018), „The influence of self-congruity and satisfaction on destination loyalty: a case pf the Korean DMZ“", Journal of Heritage Tourism, Vol. 13, No. 3, pp. 224-236.

Kim, E., Chiang, L. and Tang, L. (2017), „Investigating wellness tourists' motivation, engagement and loyalty: in search of the missing link“, Journal of Travel and Tourism Marketing, Vol. 34, No. 7, pp. 867879.

Küdra, A. and Kerem, K. (2020), "Mediating role of perceived festival value in the relationship between experiences and satisfaction", in International Journal of Event and Festival Management, Vol. 11, No., 2, pp. 255-271.

Larsen, S. (2007), „Aspects of a psychology of the tourist experience“, Scandinavian Journal of Hospitality and Tourism, Vol. 7, No. 1, pp. 7-18. https://doi.org/10.1080/15022250701226014

Lee, Cheng-Fei (2020), „Understanding the Factors Determining the Attractiveness of Camping Tourism: A Hierarchical Approach“, Tourism Planning and Development, Vol. 17, No. 5, pp. 556-572. https://doi.org/10.1080/21568316.2020.1758761

Lee, T.H., Jan, F.H., Tseng, C.H. and Lin, Y.F. (2018), „Segmentation by recreation experience in island-based tourism: a case study of Taiwan's Liuqiu Island“, Journal of Sustainable Tourism, Vol. 26, No. 3, pp. 362-378. http://dx.doi.org/10.1080/09669582.2017.1354865

Lee, T.H., Chang, P.S. and Luo, Y.W. (2016), „Elucidating the relationships among destination images, recreation experience, and authenticity of the Shengxing Heritage Recreation Area in Taiwan", Journal of Heritage Tourism, Vol. 11, No. 4, pp. 349-363.

Lee, T.H. and Chang, Y.S. (2012), ,The influence of experiential marketing and activity involvement on the loyalty intentions of wine tourists in Taiwan“, Leisure Studies, Vol. 31, No. 1, pp.103-121.

Lee, T.H. and Jan, F.H. (2019)," Market segmentation based on the environmentally responsible behaviors of community-based tourists: Evidence from Taiwan's community-based destinations", International Journal of Tourism Research, Vol. 21, No. 3, pp. 400-411. https://doi.org/10.1002/jtr.2272

Lee, T.H. and Jan, F.H. (2019), „Can community-based tourism contribute to sustainable development? Evidence from residents' perceptions of the sustainability“, Tourism Management, Vol. 70, pp. 368-380, https://doi.org/10.1016/j.tourman.2018.09.003.

Lee, T.H. and Jan, F.H. (2015a), „The Effects of Recreation Experience, Environmental Attitude, and Biospheric Value on the Environmentally Responsible Behavior of Nature-Based Tourists“, Environmental Management, Vol. 56, No. 1, pp. 193-208.

Lee, T.H. and Jan, F.H. (2015b), „The influence of recreation experience and environmental attitude on the environmentally responsible behavior of community-based tourists in Taiwan", Journal of Sustainable Tourism, Vol. 23, No. 7, pp. 1063-1094. 
ToSEE - Tourism in Southern and Eastern Europe, Vol. 6, pp. 817-834, 2021.

T. Cegur Radović, D. Lončarić, J. Cvelić Bonifačić: CAMPING TOURISM EXPERIENCE ...

Lee, T.H., Jan, F.H. and Huang, G.W. (2015), „The influence of recreation experiences on environmentally responsible behavior: the case of Liuqiu Island, Taiwan“, Journal of Sustainable Tourism, Vol. 23 , No. 6, pp. 947-967.

Lin, Y.H, Lee T.H. (2019), „How do recreation experiences affect visitors' environmentally responsible behavior? Evidence from recreationists visiting ancient trails in Taiwan“, Journal of Sustainable Tourism, Vol. 28, No. 5, pp. 705-726., https://doi.org/10.1080/09669582.2019.1701679

Lončarić, D., Dlačić, J. and Kos Kavran, A. (2018), „Improving quality of life through co-creating tourist experience - what does experience marketing have to do with it?", Ekonomska misao i praksa, No. 1 , pp. 103-121.

Lončarić, D., Dlačić, J. and Perišić Prodan, M. (2018), „What makes summer vacation experience memorable? an empirical study from Croatia“, Zbornik Veleučilišta u Rijeci, Vol. 6, No. 1, pp. 67-80.

Lončarić, D., Perišić Prodan, M., Dlačić, J. (2021), Memorable Tourism Experiences Inspired by the Beauty of Nature, Tourism and hospitality Management, Vol. 27, No. 2, pp. 315-337.

Manthiou, A., Kang, J., Chiang, L. and Tang, L. (2016), „Investigating the Effects of Memorable Experiences: an Extended Model of Script Theory", Journal of Travel and Tourism Marketing, Vol. 33, No. 3 , pp. 362-379., http://www.tandfonline.com/doi/full/10.1080/10548408.2015.1064055.

Mikulić, J., Prebežec, D., Šerić, M. and Krešić, D. (2017), „Campsite choice and the camping tourism experience: Investigating decisive campsite attributes using relevance-determinance analysis“, Tourism Management, Vol. 59, pp. 226-233.

Milohnić, I. and Cvelić-Bonifačić, J. (2015), "Sustainable camping management: A comparative analysis between Campsites and Hotels in Croatia", in $3^{\text {rd }}$ International Scientific Conference ToSEE Tourism in Southern and Eastern Europe 2015: Sustainable Tourism, Economic Development and Quality Life, Vol. 3, pp. 211-222.

Milohnić, I., Cvelić Bonifačić, J. and Licul, I. (2019), "Transformation of Camping into Glamping - trends and perspectives", in $5^{\text {th }}$ International Scientific Conference ToSEE - Tourism in Southern and Eastern Europe 2019; Creating Innovative Tourism Experiences: The Way to Extend the Tourist Season, Vol. 5, pp. 457-473.

Mehmetoglu, M. and Engen, M., (2011), „Pine and Gilmore's Concept of Experience Economy and Its Dimensions: An Empirical Examination in Tourism“, Journal of Quality Assurance in Hospitality and Tourism, Vol. 12, No. 4, pp. 237-255. http://www.tandfonline.com/doi/abs/10.1080/1528008X.2011.541847

Moise, M.S., Gil-Saura, I. and Ruiz-Molina, M.E. (2018), "Effects of green practices on guest satisfaction and loyalty”, European Journal of Tourism Research, Vol. 20, pp. 92-104.

Morgan, M. and Xu, F. (2009), „Student travel experiences: Memories and dreams“, Journal of Hospitality and Leisure Marketing, Vol.18, No. 2-3, pp. 216-236.

Neuhofer, B., Buhalis, D. and Ladkin, A. (2013), „Experiences, Conceptual experiences co-creation an Technology: A Conceptual approach to enhance tourism experiences", Tourism and Global Change: On the Edge of Something Big, CAUTHE, 2013 Conference Proceedings, pp. 546-555.

Oh, H., Fiore, A.M. and Jeoung, M. (2007), „Measuring experience economy concepts: Tourism applications“ Journal of Travel Research, Vol. 46, No. 2, pp.119-132.

O’Neill, M.A., Riscinto-Kozub, K.A. and Van Hyfte, M. (2010), „Defining visitor satisfaction in the contex of camping oriented nature-based tourism-the driving force of quality“, Journal of Vacation Marketing, Vol.16, No. 2, pp. 141-156., https://doi.org/10.1177/1356766710364541

Osman, Z. and Sentosa, I. (2013)," A study of mediating effect of trust on customer satisfaction and customer loyalty relationship in Malaysian rural tourism", European Journal of Tourism Research, Vol. 6, No. 2, pp. 192-206.

Pine, B.J. and Gilmore, J.H. (2013), "The experience economy: past, present and future", in Handbook on the experience economy, Ch. 2. Edward Elgar Publishing. https://doi.org/10.4337/9781781004227.00007

Preko, A., Gyepi-Garbrah, T.F., Arkorful, Akolaa, A.A. and Quansah, F. (2020), Museum experience an satisfaction: moderating role of visiting frequency, International Hospitality Review, Vol. 34, No. 2, pp. 203-220. https://doi.org/10.1108/IHR-04-2020-0009

Rantala, O. and Varley, P. (2019), „Wild camping and the weight of tourism“, Tourist Studies, Vol. 19, No. 3 , pp. 295-312. https://doi.org/10.1177/1468797619832308

Rogerson, C.M. and Rogerson, J.M. (2020), „Camping tourism: A review of recent international scholarship”, GeoJournal of Tourism and Geosites, Vol. 28, No. 1, pp. 349-359. https://doi.org/10.30892/gtg28127474

Schmitt, B. (2011), „Experience Marketing: Concepts, Frameworks and Consumer Insights, Foundations and Trends in Marketing“, Vol. 5, No. 2, pp. 55-112. https://doi.org/10.1561/1700000027

Sheng, C. and Chen, M. (2013), „Tourist experience expectations: questionnaire development and tex narrative analysis“, International Journal of Culture, Tourism and Hospitality Research, Vol. 7 , No. 1, pp. 93-104. http://www.emeraldinsight.com/doi/10.1108/17506181311301390 
ToSEE - Tourism in Southern and Eastern Europe, Vol. 6, pp. 817-834, 2021.

T. Cegur Radović, D. Lončarić, J. Cvelić Bonifačić: CAMPING TOURISM EXPERIENCE ...

Sotiriadis, M. (2017), „Experiential dimensions and their influence on behavioral intentions within the context of nature-based tourism“, Tourism and Hospitality Management, Vol. 23, No. 1, pp. 35-50.

Suhartanto, D., Dean, D., Chen, B.T. and Kusdibyo, L. (2020), „Tourist experience with agroturism attractions: what leads to loyalty?", Tourism Recreation Research, Vol. 45, No. 3, pp. 364-375. https://doi.org/10.1080/02508281.2020.1736251

Suhartanto, D., Dean, D., Wibisono, N., Astor, Y., Muflih, M., Kartikasari, A., Sutrisno, R. and Hardiyanto, N. (2020), ,Tourist experience in Halal tourism: what leads to loyalty?", Current Issues in Tourism Vol. 19, No. 10, pp. 966-980. https://doi.org/10.1080/13683500.2020.1813092

Suhartanto, D., Ruhadi and Triyuni, N. (2016), "Tourist loyalty toward shopping destination: the role of shopping satisfaction and destination image", European Journal of Tourism Research, Vol. 13, pp. 84-102. https://doi.org/10.54055/ejtr.v13i.233

Tan, W.K. (2017), „The relationship between smartphone usage, tourist experience and trip satisfaction in the context of a nature-based destination", Telematics and Informatics, Vol. 34, No. 2, pp. 614-627.

Triantafillidou, A. and Petala, Z. (2015), „The Role of Sea-Based Adventure Experiences in Tourists' Satisfaction and Behavioral Intentions“, Journal of Travel and Tourism Marketing, Vol. 33, Sup. 1, pp. 67-87.

Van Heerden, C.H. (2020), „Motivation and Involvement in Camping - A Gender Perspective“, African Journal of Hospitality, Tourism and Leisure, Vol. 9, No. 1, pp. 1-14.

Vesci, M., Conti, E., Rossato, C. and Castellani, P. (2020) „The mediating role of visitor satisfaction in the relationship between museum experience and word of mouth: evidence from Italy", The TQM Journal, Vol. 33, No. 1, pp. 141-162. https://doi.org/10.1108/TQM-02-2020-0022

Vrtodušić Hrgović, A.-M., Cvelić Bonifačić, J. and Licul, I. (2018), "Glamping - New outdoor accommodation", Ekonomska misao i praksa, No. 2, pp. 621-639.

Vrtodušić Hrgović, A.-M., Cvelić Bonifačić, J., Milohnić, I. (2019), „Dimensions of service quality in glamping“, in $5^{\text {th }}$ International Scientific Conference ToSEE - Tourism in Southern and Eastern Europe 2019; Creating Innovative Tourism Experiences: The Way to Extend the Tourist Season, Vol. 5, pp. 773-785.

Xu, S., Kim, H. J., Liang, M. and Ryu, K. (2018), „Interrelationships between tourist involvement, tourist experience, and environmentally responsible behavior: A case study of Nansha Wetland Park, China“, Journal of Travel and Tourism Marketing, Vol. 35, No. 7, pp. 856-868. https://doi.org/10.1080/10548408.2018.1439429

Zang, J. and Walsh, J. (2020), ,Tourist Experience, Tourist Motivation and Destination Loyalty for Historic and Cultural Tourists“, Social Sciences and Humanities, Vol. 28, No. 4, pp. 3277-3296. http://doi.org/10.47836/pjssh.28.4.43

Tihana Cegur Radović, PhD., Senior Lecturer

Karlovac University of Applied Sciences

Bussines Department

Trg J.J. Strossmayera 9, Karlovac, Croatia

+385917301596

tcradovic@vuka.hr

Dina Lončarić, PhD., Associate Professor

University of Rijeka

Faculty of Tourism and Hospitality Management

Primorska 46, p.p. 97, 51410 Opatija, Croatia

+38551294187

dinal@fthm.hr

Josipa Cvelić Bonifačić, PhD., Assistant Professor

University of Rijeka

Faculty of Tourism and Hospitality Management

Primorska 46, p.p. 97, 51410 Opatija, Croatia

+38598442877

jcvelic@fthm.hr 